\title{
Integrated geophysical appraisal of crustal architecture in the eastern Lachlan Orogen
}

\author{
Nicholas G. Direen ${ }^{1}$ Patrick Lyons ${ }^{2} \quad$ Russell J. Korsch ${ }^{3}$ Richard A. Glen ${ }^{4}$ \\ Key words: gravity, magnetics, forward modelling, seismic reflection, Macquarie Arc, tectonics
}

\begin{abstract}
Forward modelling of potential field data, combined with new geological mapping and deep seismic reflection transects acquired by the Australian Geodynamics Cooperative Research Centre (AGCRC) and New South Wales Department of Mineral Resources, has led to iterative testing of models of crustal architecture of the eastern Lachlan Orogen in New South Wales. This integrated analysis has led to new conclusions about the subsurface that are unlikely to be deduced solely from any of the individual data sets used.
\end{abstract}

Conclusions supported by the consideration of these data include:

- Presence of lower crust in the eastern Lachlan Orogen, characterised by higher than average crustal density, high P- wave velocities, and repeated, stacked bands of strong reflectivity. This crust is interpreted to be a stacked pile of metaturbidites and modified oceanic crust (greenstones).

- Presence of large volumes of Ordovician volcanic rocks underlying many areas of Silurian-Devonian basin rocks.

- Evidence for extensive, deep-cutting blind thrust faults and detachments throughout the crustal section. Major movements on these faults during the early Silurian appear to have significantly thickened the whole crust.

- Evidence for many high-level upper crustal slivers, mostly formed during the Carboniferous.

- Differences between the western Ordovician Junee-Narromine Volcanic Belt and the eastern Ordovician Molong Volcanic Belt. The former is quite dense, and is inferred to have a large volume of lavas and intrusive rocks. Its structural style is predominantly that of an imbricate stack around a deeper-rooted core. The latter has lower bulk density, and a higher volume of volcaniclastic material. It is now entirely composed of thin, imbricate slices. These differences suggest that the eastern belt may be the rifted off forearc or apron of the western belt which may be the original magmatic centre.

- Evidence for different styles of granite intrusion, reflected in different intrusive geometry of Silurian, Devonian and Carboniferous granites.

Australian Geodynamics CRC-AGSO-Geoscience Australia GPO Box 378 Canberra ACT 2601

Nick.Direen@agso.gov.au

AGCRC-AGSO-Geoscience Australia

Patrick.Lyons@agso.gov.au

AGCRC-AGSO-Geoscience Australia

Russell.Korsch@agso.gov.au

AGCRC-Geological Survey of NSW

glenr@minerals.nsw.gov.au

\section{INTRODUCTION}

The Eastern Belt of the Lachlan Orogen (Glen, 1998a) is one of a series of near-meridional structural belts which constitute the Neoproterozoic to Mesozoic Tasmanides of eastern Australia. It consists of three deformed, north-south-trending Ordovician volcanic-volcaniclastic-intrusive belts, separated by 'troughs' and 'shelves' of folded sedimentary and volcanic rocks ranging in age from Early Silurian to Middle Devonian (Glen, 1998b) (Fig. 1). These fundamental blocks are, in turn, overlain by covering basins of Late Devonian to Neogene age. Older Cambrian volcanic seafloor crust (Crawford and Keays, 1978), exposed in the western Lachlan, is not exposed in the eastern part of the orogen, and the nature and age of the basement, and the process of crustal assembly of this sector remain contentious (e.g., Collins, 1998).

Previous workers identified three major contractional events in this part of the Lachlan Orogen: these took place in the Late Ordovician-Early Silurian; Early to Middle Devonian; and Carboniferous. In each case, deformation was associated with subsequent granite plutonism, and in some cases, volcanism (e.g., Lyons, 2000a). The style of all of these deformation events has been inferred from field evidence to be thin-skinned, as outlined by Glen (1998a).

As part of its contribution to the geological understanding of Australian mineral provinces, the Australian Geodynamics Cooperative Research Centre (AGCRC), in conjunction with the New South Wales Department of Mineral Resources (NSWDMR), acquired six deep seismic transects over major structures within the eastern Lachlan Orogen (Fig. 1). In the east, three lines were acquired across parts of the boundaries between the Molong Volcanic Belt (MVB) and its bounding sedimentary packages. A further three lines were acquired over the Parkes-Narromine and Temora-Lake Cowal sub-belts (Fig. 1) of the Junee-Narromine Volcanic Belt (JNVB), the overlying Silurian-Devonian Jemalong Trough, and flanking Ordovician Wagga Group (west) and Kirribilli Formation (east) (Fig. 1). The two Ordovician volcanic belts, together with the Rockley-Gulgong Volcanic Belt to the east (Fig. 1), constitute the postulated Macquarie Arc. It is considered to have been a single arc built on Cambrian oceanic crust, and later dismembered (Glen et al., 2000; Glen et al., 1998b). The Ordovician turbidite belts (Fig. 1) may have been deposited in forearc and/or backarc positions. However, the boundary relationships between these two rock packages are often obscure in the field, thus limiting tectonic inferences from mapping. The importance of the deep, sub-surface relationships of these rock packages necessitates a geophysical approach in order to understand the development of the Orogen.

Results of processing and preliminary interpretation of the seismic reflection data are published elsewhere (Glen et al., in press; Jones and Johnstone, 2001; Glen et al., 2001; Glen et al., 2000; Glen et al., 1998a). The purpose of this companion paper is to provide information about additional testing and constraints placed on seismic reflection interpretations using potential field data and forward modelling. 


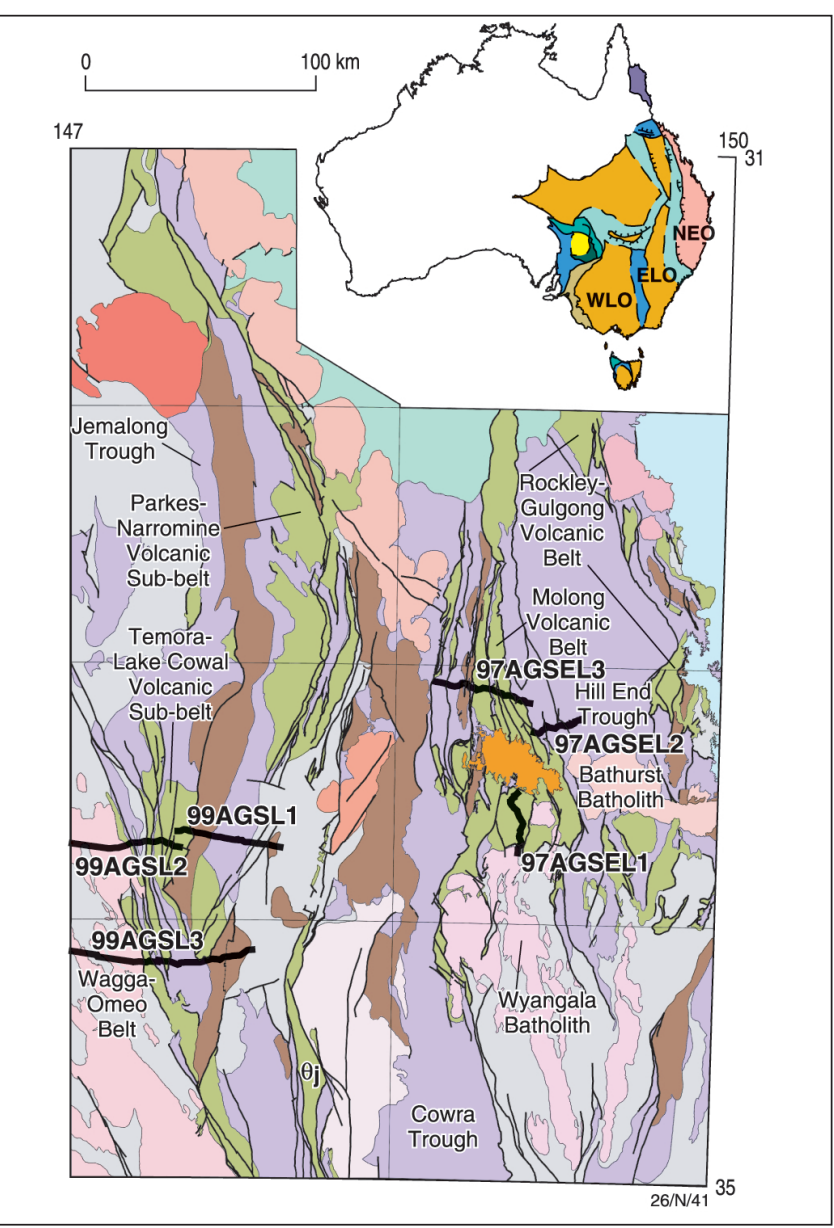

Fig. 1. Main figure: Location map -eastern belt of the Lachlan Orogen, within the Tasmanides of Eastern Australia (inset). The main lithotectonic groupings (volcanic belts and "troughs") are labelled. Seismic lines used in this study are shown.

Key: (Inset) WLO = western belt of the Lachlan Orogen; ELO (blue and orange bands) = eastern belt of the Lachlan Orogen. NEO = New England Orogen (pink). The contact between the NEO and ELO is overlain by the Sydney-Bowen Basin system (aqua tones).

Key: (Main Figure): Ordovician quartz turbidites = grey. Ordovician "volcanics" = green. $\theta \mathbf{j}=$ Ordovician Jindalee Group. Silurian granites $=$ pink. Silurian-Devonian sedimentary rocks = lilac. Devonian granite plutons $=$ deep pink. Devonian quartzose clastics $=$ brown. Carboniferous granite plutons $=$ pale pink. Canobolas Tertiary Igneous Volcanic complex $=$ orange.

The Junee-Narromine Volcanic Belt (JNVB) comprises the Parkes Narromine Volcanic sub-belt and the Temora-Lake Cowal Volcanic sub-belt, which are linked at depth. The Wagga-Omeo Belt is constituted by the Wagga Group (grey) and the granites of the Ungarie Suite (pale pink) (Lyons, 2000a). The Kirribilli Formation includes the grey units to the east of the 1999 seismic lines, and west of the Cowra Trough; the Girilambone Group comprises the grey units to the north of the 1999 seismic lines, and the Adaminaby Group are the grey units around the Wyangala Batholith.

In particular, we seek to answer the following questions:

1. Do potential field data corroborate the fault geometry and structural style interpreted from seismic reflection data?

2. Do potential field data support the interpretation of large volumes of Ordovician igneous rocks inferred from the seismic reflection data?

3. Do potential field data confirm the seismic interpretations of boundaries between Ordovician volcanic and intrusive rocks and
Ordovician turbidites, given the petrophysical contrasts between them?

4. What extra information is available from potential field data about the extents of Silurian and Devonian sedimentary and volcanic packages?

5. What information is available from potential field data about non-reflective granites and their volumes?

6. What inferences can be made about the nature of the cryptic lower crust of the eastern Lachlan Orogen?

Answers to these questions can independently test and strengthen the conclusions made from the seismic interpretation. By increasing the robustness of the interpretation, they can also help to constrain tectonic models for the development of the Ordovician Macquarie Arc, and its subsequent dismemberment. Accurate knowledge of the current positions of the arc fragments, and their interaction with major structures, is important, as the remnant arc appears to control the position of $\mathrm{Cu}$ and $\mathrm{Au}$ mineralisation in the eastern Lachlan Orogen (Glen, 1995).

\section{DATA}

Acquisition of seismic reflection data sets was undertaken by the Australian National Seismic Imaging Resource (ANSIR) for NSWDMR and the AGCRC in 1997 (eastern lines) and 1999 (western lines). Lines acquired in 1997 were shot using conventional downhole explosive sources, with a 300 m shotpoint interval and $50 \mathrm{~m}$ group interval. Nominal fold achieved was 10, with data recorded to $20 \mathrm{~s}$ two-way travel time (TWT). Lines recorded in 1999 used three IVI Hemi-60 vibroseis systems, utilising three 10-second monosweeps from $6 \mathrm{~Hz}$ to $90 \mathrm{~Hz}$, and a group interval of $40 \mathrm{~m}$. Shot point interval was either $40 \mathrm{~m}$ or $80 \mathrm{~m}$. Nominal fold achieved was $120 \times$ or $60 \times$, and data were recorded to $20 \mathrm{~s}$ TWT (Jones and Johnstone, 2001). Further acquisition and processing parameters are also described in Jones and Johnstone (2001). It is important to note that, in contrast to the 1999 lines, 1997 lines were not migrated, so maximum apparent dips of features imaged on these lines cannot be greater than $45^{\circ}$ (Jones and Johnstone, 2001).

Gravity values for this study were extracted from the Australian National Gravity Database, subsequently released in 2000 (Murray, 2000). The original readings were taken along seismic lines at an approximate interval of $300 \mathrm{~m}$. Positioning of these stations was via a differential GPS method, producing vertical accuracy of $\pm 10 \mathrm{~cm}$, and horizontal accuracy of $\pm 1 \mathrm{~cm}$. Data were processed to Simple Bouguer Anomalies using the 1971 IGSN Gravity Formula, the GRS 80 ellipsoid, and a reduction density of $2.80 \times 10^{3} \mathrm{~kg} \mathrm{~m}^{-3}$. The higher than 'normal' (i.e. $2.67 \times 10^{3} \mathrm{~kg} \mathrm{~m}^{-3}$ ) reduction density was chosen empirically to minimise the DC shift between model and observed field anomalies, thus obviating the need for an artificial 'regional' removal. The assumption of a high regional density affects the apparent absolute density values of modelled bodies, but not their contrasts, which remain fixed. In general terms, this high value appears to reflect the contribution of a dense deep crustal component to the field. Terrain corrections have not been applied to any of the data. In the hilly country around the 1997 lines, this assumption leads to a calculated error in the Bouguer anomaly. These errors range up to approximately $55 \mu \mathrm{ms}^{-2}$ in one extreme instance. More typical values for the terrain correction are estimated to be $5-10 \mu \mathrm{ms}^{-2}$ for most stations on these lines. All Bouguer values used in the modelling of these lines are thus slightly lower than true values.

Reduced-to-pole total magnetic intensity data with the AGRF removed were extracted from merged and levelled grids for the Bathurst, Forbes, and Cootamundra 1: 250000 map sheet areas (Mackey, unpublished data; and Fig. 2). These data were acquired 

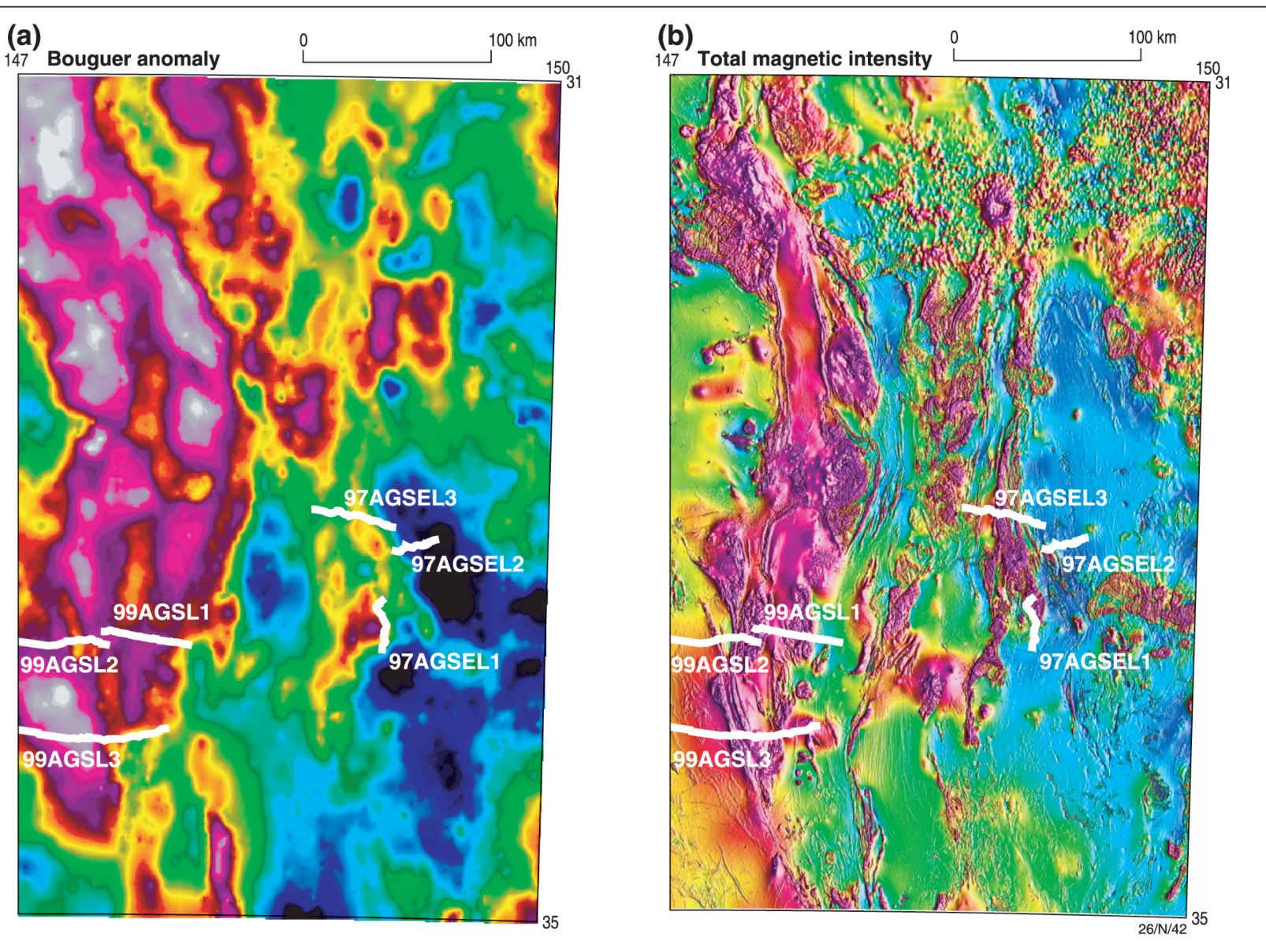

Fig. 2. (a) Bouguer gravity anomaly, density $2.80 \times 10^{3} \mathrm{~kg} \mathrm{~m}^{-3}$ and (b) total magnetic intensity (reduced to the pole) images of the eastern belt of the Lachlan Orogen, with seismic lines shown. Images use comtal (white high, black low) and pseudocolour (pink high, blue low) colour palettes respectively, and have been stretched using histogram equalisation.

between 1991 and 1998 for the NSW Department of Mineral Resources and AGSO. Lines were flown east-west, either as $80 \mathrm{~m}$ or $100 \mathrm{~m}$ drapes, with spacings of $200 \mathrm{~m}$ to $400 \mathrm{~m}$. The levelling process for these datasets also entailed the addition of an arbitrary constant (typically $5000 \mathrm{nT}$ : T. Mackey pers. Comm, 2001) to the residual values. This was to bin the data with positive values for image processing and display. Further details of acquisition and processing of the magnetic data are given in Richardson (2000).

\section{METHODS}

Interpretations of the seismic reflection data (e.g., Glen et al., 2001; Glen et al., 2000; Glen et al., 1998a) were combined with detailed structural traverse and drillhole information acquired during regional mapping (Pogson and Watkins, 1998; Lyons et al., 2000a; Warren et al., 1996). The surface-constrained interpretations were digitised using a standard interpretation package (Petrosys ${ }^{\mathrm{TM}}$ ), and converted to depth using a constant velocity of $6000 \mathrm{~ms}^{-1}$. This may have introduced some errors into depth estimates in the higher parts of the models where velocities may be up to $1000 \mathrm{~ms}^{-1}$ less. The depth converted interpretations were subsequently imported into a potential field modelling package (ModelVision ${ }^{\mathrm{TM}}$ ) to allow 2.5D modelling of the geophysical responses of crustal architecture from the surface to the seismic Moho. This step also involved extrapolating between the surface and the seismic datum surfaces using the geological and drillhole constraints. The generally meridional nature of the packages and bounding structures allows reasonable extrapolations to be made in the third (along-strike) dimension. The validity of many of these extrapolations has been further tested using multi-scale edge analysis ('worming') of the potential field data (Archibald et al., 2001a,b; Direen et al., 2000) which indicates the strike of magnetic and density discontinuities at depth. Models were continued in the along-strike dimension for $10 \mathrm{~km}$ in either direction, and extended from the observed data in the along-line direction for $20 \mathrm{~km}$ to $30 \mathrm{~km}$ in both directions, in order to avoid spurious edge effects. Along-line projections were constrained with reference to surface geological mapping, although at depth these projections become speculative away from the constraining seismic reflection data.

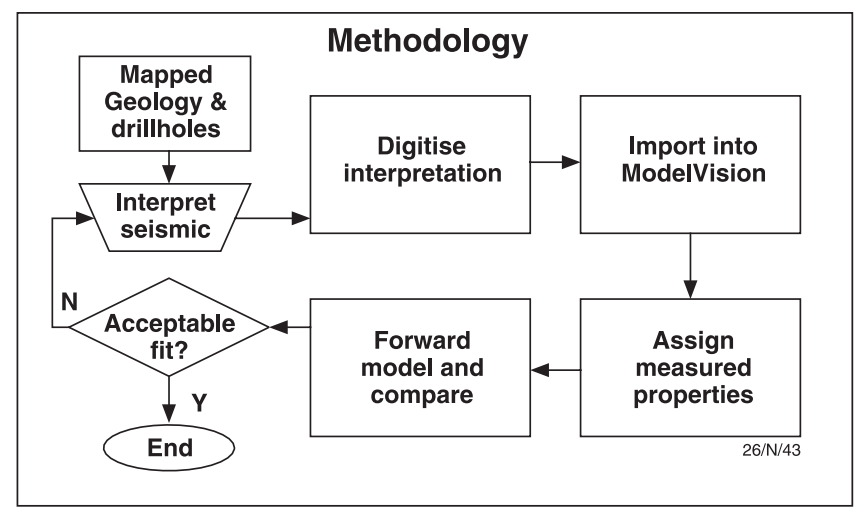

Fig. 3. Iterative method used in the study. Typically two to three cycles per seismic section were required to develop a consistent solution. 


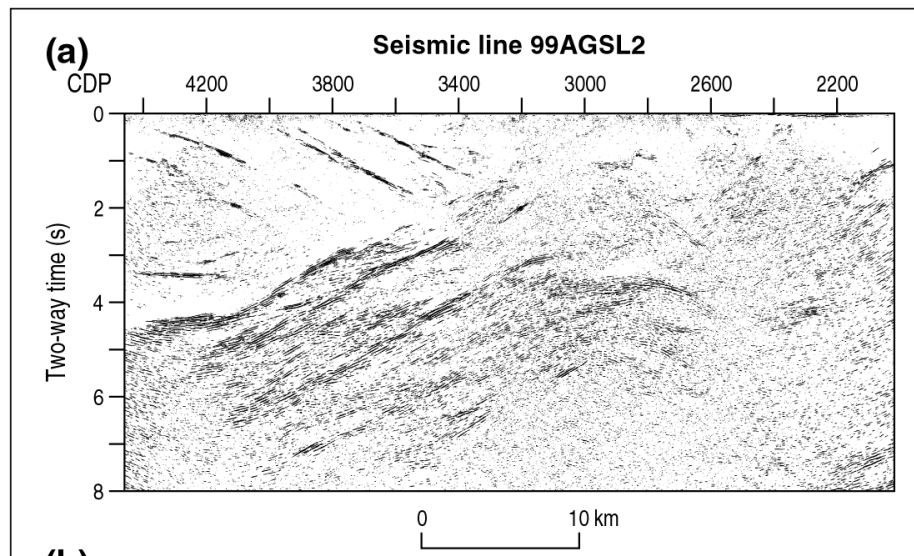

(b)
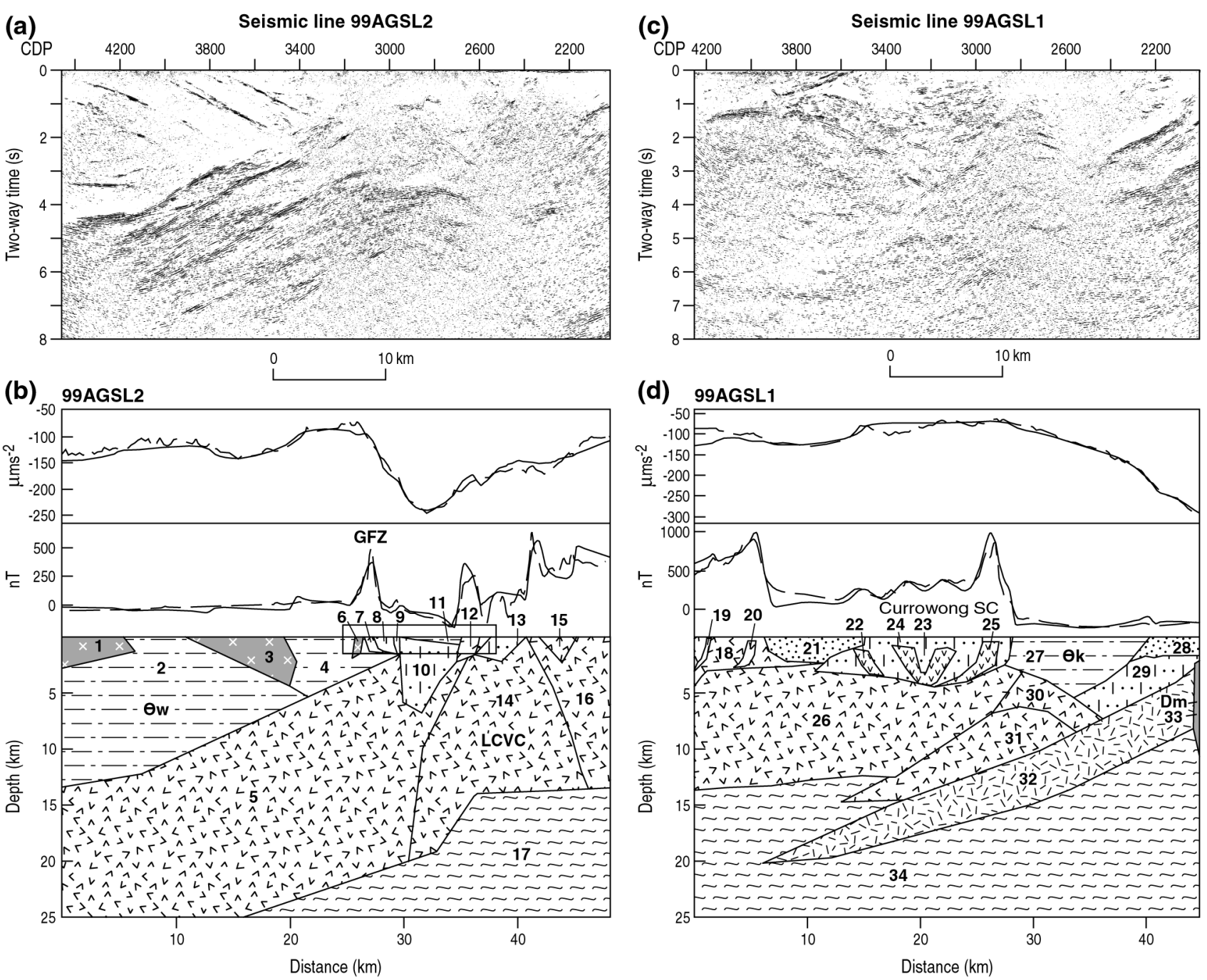

(d) 99AGSL1

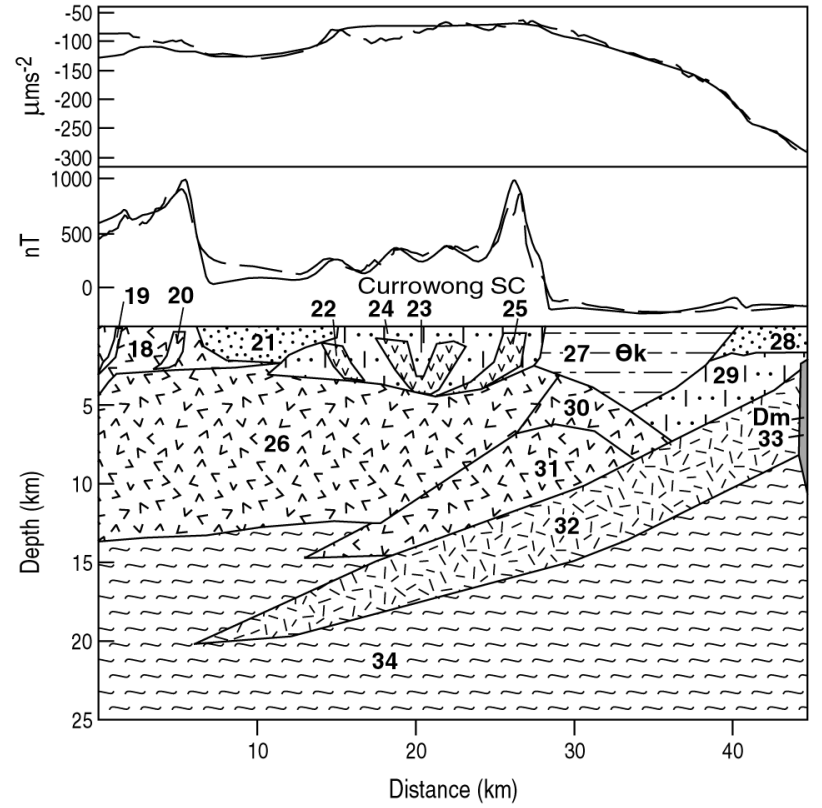

Fig. 4. Uninterpreted migrated 8 second TWT seismic sections acquired in 1999, and modelled sections over the Junee-Narromine Volcanic Belt:

(a) 99AGSL2.

(b) Model. $\theta$ w = Wagga Group; GFZ = Gilmore Fault Zone; LCVC = Lake Cowal Volcanic Complex. Inset box - see Fig. 4e.

(c) 99AGSL1.

(d) Model. $\theta \mathrm{k}=$ Kirribilli Formation; Dm = Mortray Hill Granite Complex.

(e) Preliminary seismic interpretation of 99AGSL2 between CDP 3200 and 2400, showing initial interpreted thickness $\left(\right.$ c. $2.5 \mathrm{~km}$ ) of Ordovician turbidites (density $2.71 \times 10^{3} \mathrm{~kg} \mathrm{~m}^{-3}$ ). The interpreted thickness of this body was dramatically reduced in the final gravity model, due to the gravity low at this position (Fig.4b inset). The vergence of the structures around CDP 2600 was also changed to accommodate mapped information. $\theta \mathrm{w}=$ Wagga Group; $\theta \mathrm{v}=$ Ordovician "volcanics"; $\theta \mathrm{g}=$ Girilambone Group.

Geometric models derived from seismic interpretation were then constrained by comprehensive (but not exhaustive) data sets of physical properties compiled from measurements on proprietary drillcores and bulk sampling in the field by the authors; some check data were also acquired from information held in the AGSO OZROX database. Nearly 200 individual wet bulk density determinations were made on $>0.5 \mathrm{~kg}$ samples of rock from 50 groups or suites. Magnetic susceptibility readings were taken at over 2900 sites representing 49 groups or suites. Density determinations were made on the freshest outcrop samples available or on drillcores; both sampling procedures avoided obvious zones of weathering, alteration, and fracturing. However, the quoted values are probably realistically minimum estimates only. No attempt was made to measure or account for remanent magnetisation of rocks. Hence, the quoted values are apparent susceptibilities only. Magnetic susceptibilities measured on drillcores have been corrected for the geometric factor due to a cylinder. The number of individual petrophysical analyses used in 


\begin{tabular}{|l|l|l|l|l|}
\hline Package & $\begin{array}{l}\text { Density range } \\
\left(\times 10^{3} \mathrm{kgm}^{-3}\right)\end{array}$ & $\begin{array}{l}\text { Number } \\
\text { of samples }\end{array}$ & $\begin{array}{l}\text { Magnetic susceptibility range } \\
(\mathrm{SI})\end{array}$ & $\begin{array}{l}\text { Number of } \\
\text { samples }\end{array}$ \\
\hline Devonian quartz clastics & $2.45-2.65$ & 8 & $0-0.0005$ & 70 \\
\hline $\begin{array}{l}\text { Silurian-Devonian sedimentary } \\
\text { rocks }\end{array}$ & $2.40-2.66$ & 43 & $0-0.001$ & 2400 \\
\hline Silurian-Devonian volcanics & $2.40-2.80$ & 10 & $0-0.05$ & 320 \\
\hline Ordovician arc "volcanics" (s.l.)** & $2.60-2.80$ & 85 & $0-0.07$ & 400 \\
\hline Ordovician Jindalee Group equivs. & $2.80-2.85$ & 4 & $0-0.07$ & 60 \\
\hline Ordovician turbidites** & $2.60-2.72$ & 10 & $0-0.12$ & 200 \\
\hline Granite plutons** & $2.50-2.69$ & 37 & $0-0.18$ & 190 \\
\hline Mid-lower crust* & 2.85 & inferred & 0 & inferred \\
\hline Upper mantle* & inferred & 0 & inferred \\
\hline
\end{tabular}

Table 1. Measured petrophysical properties of units within the eastern Lachlan Orogen.

\begin{tabular}{|l|l|l|l|l|l|l|l|l|l|l|l|}
\hline Body & $\rho \mathrm{kg} \times 10^{3} \mathrm{~m}^{-3}$ & $\mathbf{k}_{\text {app }}$ SI & Body & $\rho$ & $\mathbf{k}_{\text {app }}$ & Body & $\rho$ & $\mathbf{k}_{\text {app }}$ & Body & $\rho$ & $\mathbf{k}_{\text {app }}$ \\
\hline 1 & 2.70 & 0 & 15 & 2.68 & 0.01 & 29 & 2.55 & 0 & 43 & 2.80 & 0.14 \\
\hline 2 & 2.73 & -0.002 & 16 & 2.73 & 0.03 & 30 & 2.70 & 0 & 44 & 2.60 & 0.05 \\
\hline 3 & 2.63 & 0 & 17 & 2.85 & 0 & 31 & 2.70 & 0.05 & 45 & 2.60 & 0.05 \\
\hline 4 & 2.73 & 0.005 & 18 & 2.62 & 0.04 & 32 & 2.80 & 0.05 & 46 & 2.55 & 0.005 \\
\hline 5 & 2.78 & 0 & 19 & 2.80 & 0.03 & 33 & 2.55 & 0 & 47 & 2.60 & 0.01 \\
\hline 6 & 2.69 & 0.01 & 20 & 2.80 & 0.01 & 34 & 2.85 & 0 & 48 & 2.52 & 0 \\
\hline 7 & 2.75 & 0.025 & 21 & 2.59 & 0 & 35 & 2.65 & 0.005 & 49 & 2.52 & 0 \\
\hline 8 & 2.57 & 0 & 22 & 2.80 & 0.035 & 36 & 2.72 & 0 & 50 & 2.65 & 0 \\
\hline 9 & 2.72 & 0.01 & 23 & 2.65 & 0 & 37 & 2.67 & 0 & 51 & 2.80 & 0.07 \\
\hline 10 & 2.55 & 0 & 24 & 2.80 & 0.03 & 38 & 2.82 & 0.02 & 52 & 2.85 & 0 \\
\hline 11 & 2.65 & -0.02 & 25 & 2.80 & 0.05 & 39 & 2.85 & 0.08 & & & \\
\hline 12 & 2.70 & 0.01 & 26 & 2.68 & 0.02 & 40 & 2.85 & 0 & & & \\
\hline 13 & 2.55 & 0 & 27 & 2.62 & -0.009 & 41 & 2.85 & 0.05 & & & \\
\hline 14 & 2.68 & 0.01 & 28 & 2.47 & 0 & 42 & 2.62 & 0 & & & \\
\hline
\end{tabular}

Table 2. Modelled properties, Junee-Narromine Volcanic Belt.

\begin{tabular}{|l|l|l|l|l|l|l|l|l|l|l|l|}
\hline Body & $\rho \mathrm{kg} \times 10^{3} \mathrm{~m}^{-3}$ & $\mathbf{k}_{\text {app }}$ SI & Body & $\rho$ & $\mathbf{k}_{\text {app }}$ & Body & & $\mathbf{k}_{\text {app }}$ & Body & $\rho$ & $\mathbf{k}_{\text {app }}$ \\
\hline 1 & 2.63 & 0 & 13 & 2.72 & -0.017 & 25 & 2.65 & 0.055 & 37 & 2.66 & 0.06 \\
\hline 2 & 2.63 & 0.025 & 14 & 2.85 & 0 & 26 & 2.57 & 0.003 & 38 & 2.65 & 0.02 \\
\hline 3 & 2.62 & 0.03 & 15 & 2.57 & 0 & 27 & 2.70 & 0.025 & 39 & 2.50 & 0.01 \\
\hline 4 & 2.70 & 0 & 16 & 2.64 & 0.001 & 28 & 2.65 & 0.015 & 40 & 2.50 & -0.005 \\
\hline 5 & 2.66 & 0.07 & 17 & 2.52 & 0.002 & 29 & 2.55 & 0 & 41 & 2.55 & 0 \\
\hline 6 & 2.72 & -0.01 & 18 & 2.85 & $>1.5$ & 30 & 2.63 & 0.012 & 42 & 2.55 & 0 \\
\hline 7 & 2.74 & 0.002 & 19 & 2.52 & 0.002 & 31 & 2.55 & 0.009 & 43 & 2.63 & 0.06 \\
\hline 8 & 2.73 & -0.02 & 20 & 2.63 & 0.04 & 32 & 2.57 & 0.005 & 44 & 2.65 & -0.03 \\
\hline 9 & 2.70 & -0.016 & 21 & 2.60 & 0.05 & 33 & 2.50 & 0 & 45 & 2.55 & -0.025 \\
\hline 10 & 2.72 & 0.002 & 22 & 2.60 & 0.007 & 34 & 2.63 & 0.001 & 46 & 2.63 & 0.04 \\
\hline 11 & 2.58 & -0.012 & 23 & 2.60 & 0.007 & 35 & 2.85 & 0 & 47 & 2.85 & 0 \\
\hline 12 & 2.58 & -0.015 & 24 & 2.63 & 0.01 & 36 & 2.85 & 0 & & & \\
\hline
\end{tabular}

Table 3. Modelled properties, Molong Volcanic Belt.

this study allows estimates to be made of the averages and ranges of density and magnetic susceptibility for most of the rock packages crossed by the seismic lines. These data sets constrain one aspect of the ambiguity involved in integrating the forward models with the seismic interpretation, as the models must conform to the bounds imposed by the independent petrophysical data (Leaman, 1994).

Analysis of the sampled data sets allows identification of eight broad families of petrophysically distinct supracrustal units. From youngest to oldest, these are:

1. Regolith materials;

2. Devonian quartzose clastic units (Hervey, Catombal, and Lambie Groups);
3. Silurian and Devonian sedimentary rocks (e.g., Mumbil, Cudal, Crudine, Cootamundra, Derriwong, and Ootha Groups);

4. Silurian-Devonian volcanic and volcaniclastic rocks (e.g., Douro Group; Carawandool, Canowindra, and Dulladerry Volcanics; Blowering Formation);

5. Ordovician intrusive, volcanic and volcaniclastic rocks (e.g., Kenilworth, Cabonne and Northparkes Volcanic Groups; Lake Cowal Volcanic Complex; Temora Volcanics);

6. Ordovician sedimentary, volcanic, and hypabyssal intrusive rocks of the Jindalee Group;

7. Ordovician turbidites (e.g., Adaminaby, Girilambone and Wagga Groups; Kirribilli Formation);

8. Granite plutons of several ages. 
(a)

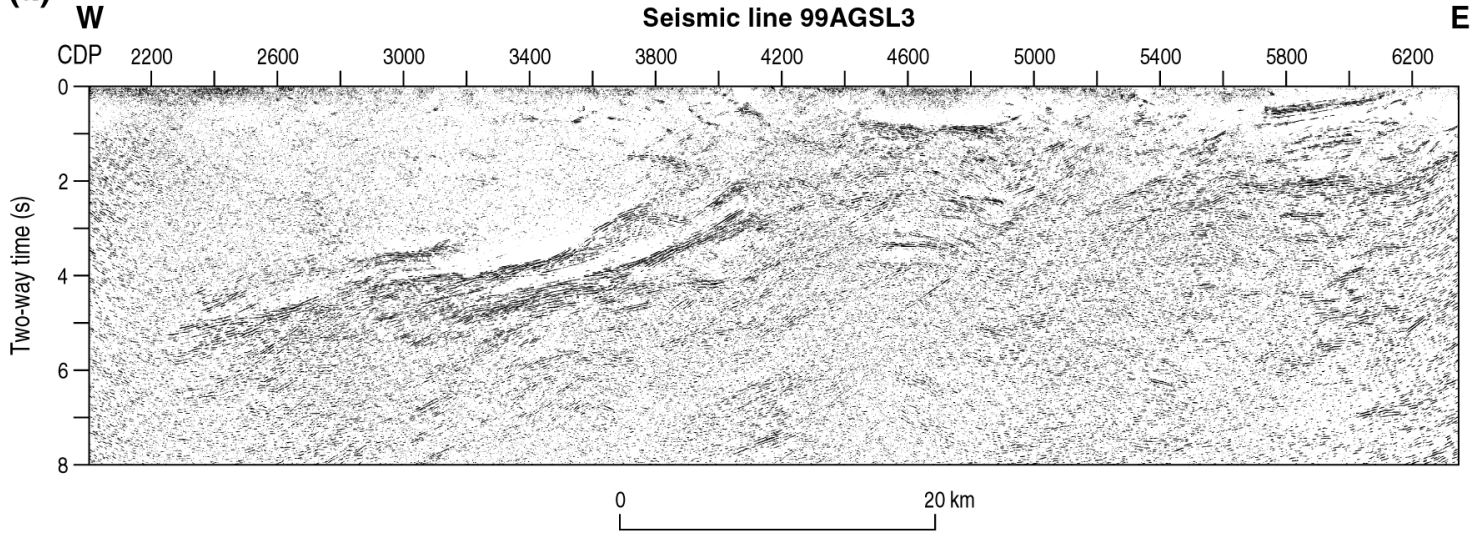

(b)

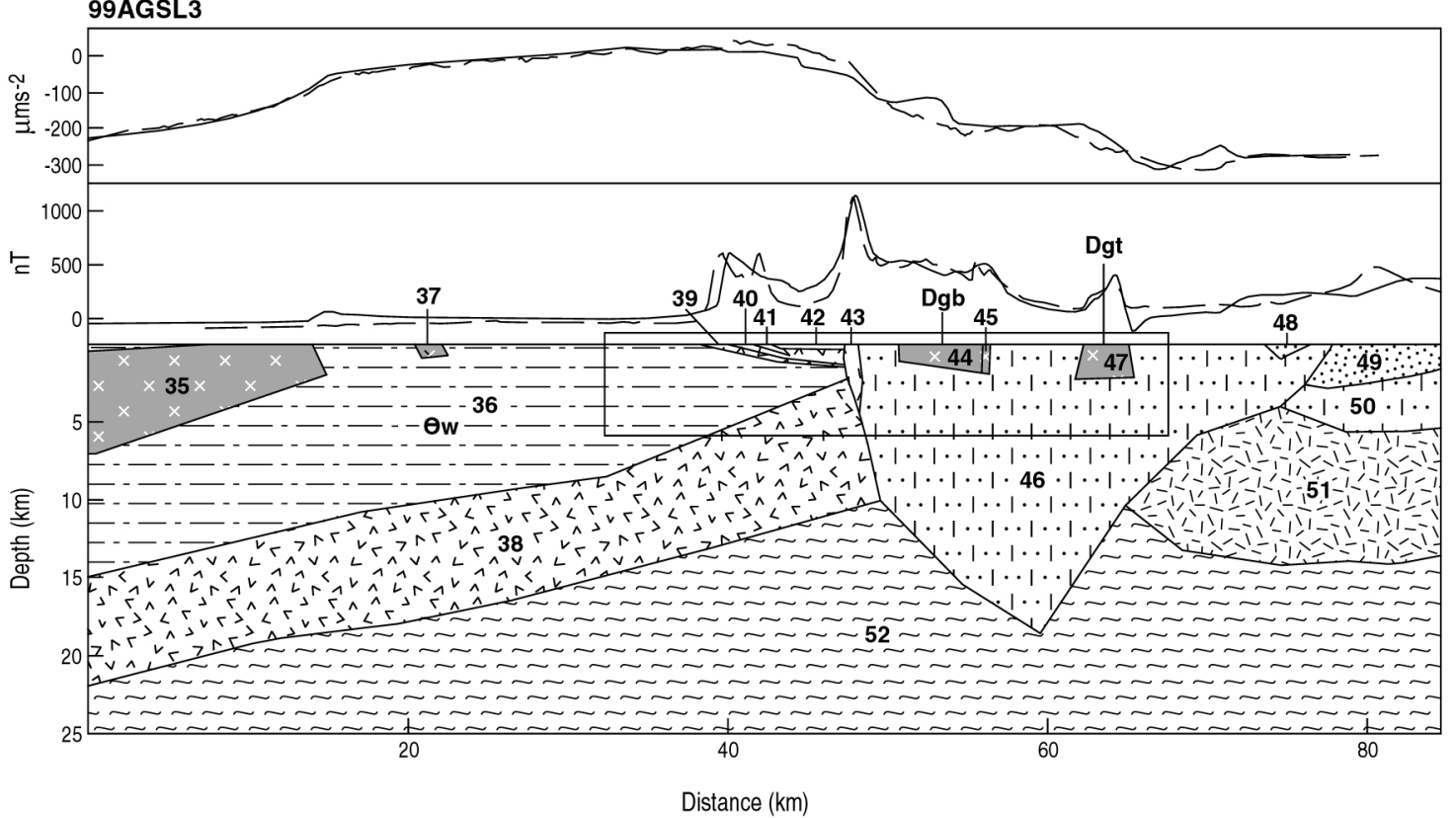

Distance $(\mathrm{km})$

\begin{tabular}{|c|c|c|c|c|c|}
\hline \begin{tabular}{|llll} 
& $\ddots$ \\
\hdashline & $\vdots$ \\
\hdashline & 0
\end{tabular} & $\begin{array}{l}\text { Late Devonian } \\
\text { quartz clastics }\end{array}$ & \begin{tabular}{|ll|l|} 
& $\cdots$ & \\
$\cdots$ & & $\cdots$ \\
\end{tabular} & $\begin{array}{l}\text { Silurian - Devonian } \\
\text { sedimentary }\end{array}$ & $-\bar{C}$ & $\begin{array}{l}\text { Ordovician quartz } \\
\text { turbidites }\end{array}$ \\
\hline 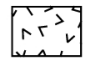 & Ordovician volcanics & 舁1, & $\begin{array}{l}\text { Ordovician Jindalee } \\
\text { Group equivalents }\end{array}$ & \begin{tabular}{|l|}
$x^{x}$ \\
$\times$
\end{tabular} & Granites \\
\hline
\end{tabular}

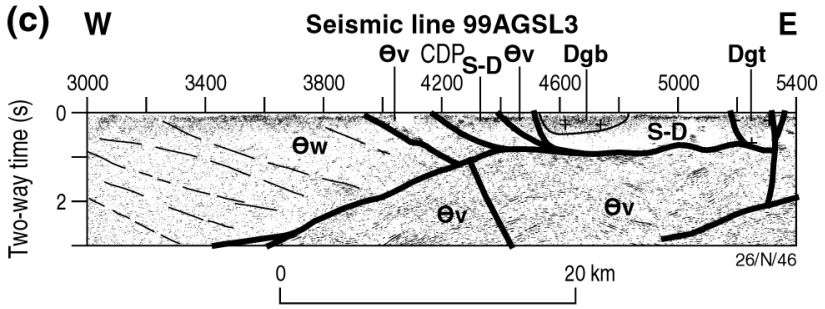

Fig. 5. Uninterpreted migrated 8 second TWT seismic section acquired in 1999, and modelled section over the Junee-Narromine Volcanic Belt:

(a) 99AGSL3.

(b) Model. Dgb = Barmedman granite; Dgt = Thurungly granite. Inset box - see Fig. 5c.

(c) Preliminary seismic interpretation of 99AGSL3 between CDP 3000 and 5400, showing initial interpreted extent of Ordovician volcanics (s.l.) (density $2.70 \times 10^{3} \mathrm{~kg} \mathrm{~m}^{-3}$ ). This interpretation was later abandoned, due to the strong negative Bouguer anomaly in this position, which requires a low density body along the Gilmore FZ. In the final model, this is represented by a Silurian-Devonian basin $\left(\right.$ density $\left.2.55 \times 10^{3} \mathrm{~kg} \mathrm{~m}^{-3}\right)$. Key: $\theta \mathrm{w}=$ Wagga Group; $\theta v$ = Ordovician "volcanics"; S-D = slices of Jemalong Trough; Dgt = Thurungly granite. 


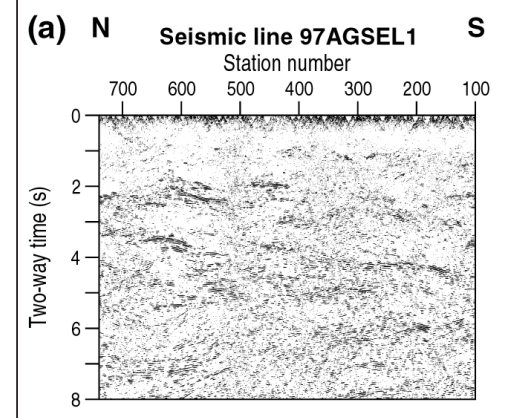

(b) 97AGSEL1
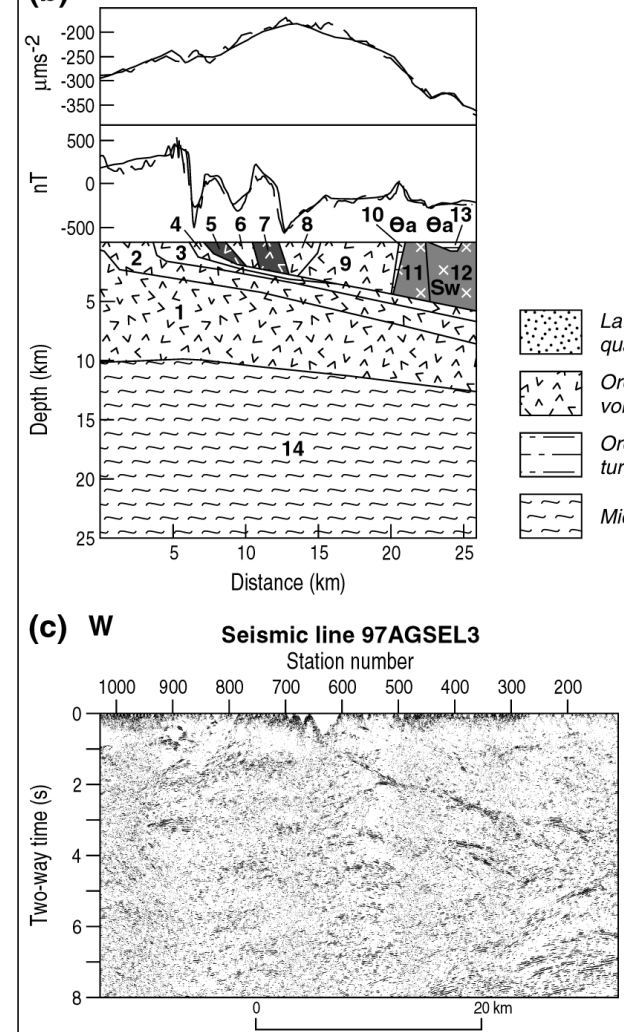

(d) 97AGSEL3

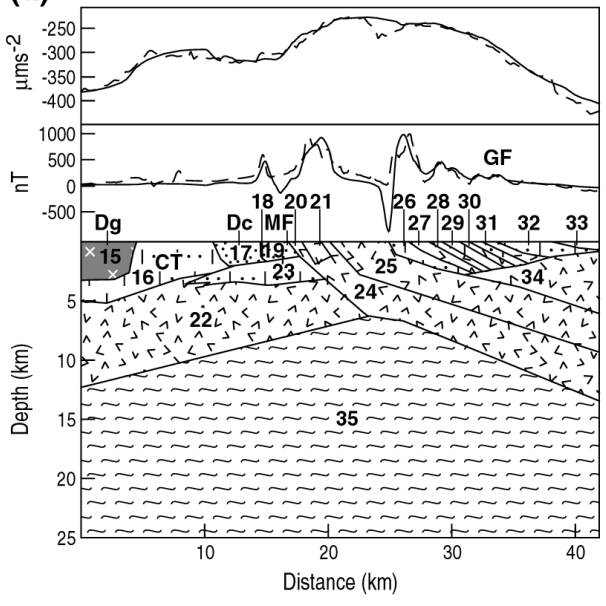

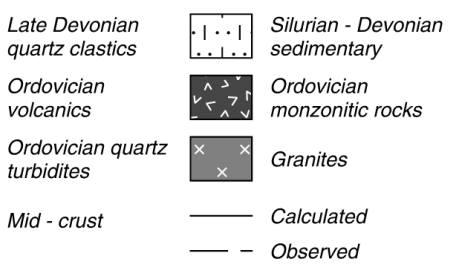

(e) Seismic line 97AGSEL2 E Station number

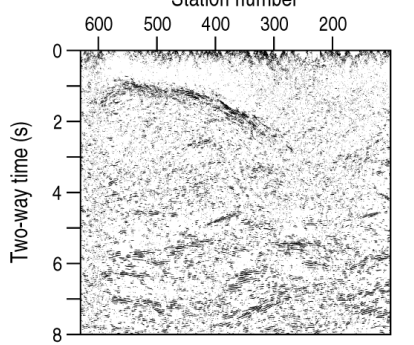

(f) 97AGSEL2

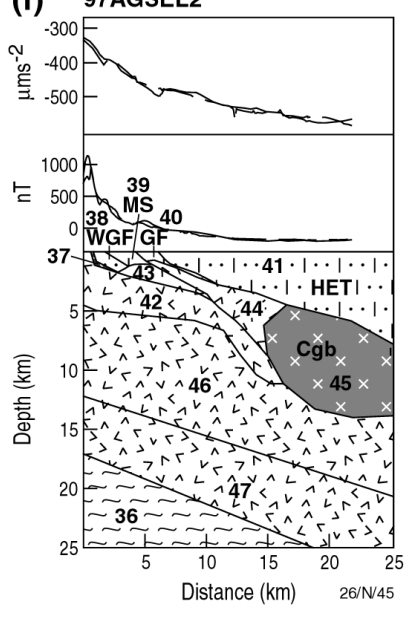

Fig. 6. 1997 Uninterpreted, unmigrated 8 second TWT seismic sections acquired in 1997, and modelled sections over the Molong Volcanic Belt.

(a) 97AGSEL1 (north-south).

(b) Model. $\theta \mathrm{a}=$ Adaminaby Group; $\mathbf{S w}=$ Wyangala Batholith. $\theta \mathrm{v}$ in dark stipple $=$ exposed monzonitic intrusives.

(c) 97AGSEL3 (east-west).

(d) Model. Dg = Gumble Granite; CT = Cowra Trough; Dc = Catombal Group; MF = Molong Fault; GF = Godolphin Fault.

(e) 97AGSEL2 (east-west).

(f) Model. $\theta \mathrm{v}$ in dark stipple = ultramafic complex; WGF = Wilga Glen Fault; MS = Mumbil Shelf; GF = Godolphin Fault; HET = Hill End Trough; Cgb = Bathurst Batholith.

In addition, the properties of middle to lower crustal and mantle materials were derived from seismic refraction results (Finlayson et al., 1998). The ranges of properties measured (in the case of supracrustal packages) or derived from P-wave velocities (mid-crust to mantle) are shown in Table 1.

The extensive surface and subsurface sampling represented in this petrophysical data set is of great utility in the qualitative interpretation of the regional Bouguer anomaly and total magnetic intensity images (Fig. 2). For example, areas of subcropping Ordovician volcanic and volcaniclastic rocks, with generally high densities and high apparent magnetic susceptibilities, are recognisably associated with distinct belts of high amplitude, long wavelength Bouguer and magnetic anomalies (Figs. 1 and 2). Conversely, Late Devonian quartzose clastic rocks, with low densities and low apparent susceptibilities, are associated with distinct belts of negative Bouguer anomalies, and texturally smooth magnetic responses (Figs. 1 and 2). Thus, these data sets were of use in refining existing 'solid geology' interpretations of the geophysical data (e.g., Bacchin et al., 1999), and have resulted in a single revised interpretation map of the eight 1:250 000 sheet areas covering this part of the Orogen (Fig.1 and Raymond et al., 2000a).

The final stage of our method in deriving meaningful crustal architectural models was to concurrently forward model the gravity and magnetic fields arising from the interpreted seismic geometry-petrophysical property distribution and to compare the computed fields to the observed fields. In most cases, this resulted in an unacceptable fit of modelled and observed fields, requiring modification of either the seismic interpretation, the assigned properties, or both, and iterative remodelling. The overall method is outlined in Figure 3. Long-wavelength negative magnetic anomalies (below regional background), that are modelled with bodies of apparent negative susceptibility, are probably an expression of first order polynomial tilts applied to individual grids during the levelling process (T. Mackey, pers. Comm, 2001). These tilts result in the residual data being shifted below the AGRF. Alternatively, some negative anomalies may be the expression of subtle remanence effects. In any case, the modelled susceptibility values are relative contrasts within the model only, and should be compared to the measured contrasts for consistency. Because of the minimalist approach adopted and the inverse square law, there is also considerably more complexity in the deeper crustal sections ( $>10 \mathrm{~km}$ ) than is depicted in the models. It is also likely that there may be significantly more granite present in the upper crust (c.2-10 km), which has not been recognised in the seismic data due to low reflectivity contrast, or in the potential fields due to aliasing and lack of constraints on non-unique interpretations at depth. These are global problems (cf. Evans et al., 1994; Vigneresse, 1990), so the principle of caveat emptor applies. 


\section{RESULTS}

Model iterations were guided by the five criteria defined by Leaman (1994). These are 1) honouring available geological control; 2) not including unsustainable discontinuities in either geometry or properties; 3 ) honouring measured or readily inferred properties; 4) being based on several profiles across the available datasets; and 5) having a consistently derived regional field level in processing and model interpretation.

The final models present a consistent solution set constrained by field evidence, seismic reflectivity, and observed density and magnetic susceptibility contrasts. In general, no attempt has been made to account for high-frequency features in the potential fields. Instead, the broad, regional features have been modelled, consistent with an attempt to derive a coherent style of solution across the eastern Lachlan Orogen.

In this regard, we have ignored the contribution to the modelled gravity field from near-surface weathering and transported regolith. Test models over the well-developed palaeochannel and weathered features shown in Gibson and Chan (1999) and Raymond et al. (2000b), which were constrained by both outcrops and drilling, indicate that the contribution from regolith features is minor. Accounting for weathering profiles down to $200 \mathrm{~m}$ in the test models only requires variation to the inferred properties of the underlying rock by $+1-2 \%$, which is well within the error range of the fresh samples used to derive the properties.

\section{Crustal architecture of the Junee-Narromine Volcanic Belt and flanking basins}

Uninterpreted seismic sections for the three 1999 seismic lines are shown in Figures 4 and 5. The final models of the interpretations are also shown. The following conclusions, addressing the six questions posed, have been drawn from the models:

1. The potential field data are consistent with interpretations of the seismic reflection data that invoke early deep-cutting structures (i.e. involving mid- and lower crustal rocks) overprinted by later upper crustal thrusts (Glen et al., 2001; Glen et al., 2000; Glen et al., 1998a). The deep-cutting style is particularly apparent in the imaged (to $5 \mathrm{sec}$ TWT) and modelled $(\sim 13 \mathrm{~km})$ thicknesses of Wagga Group in the west. The seismic reflections show east-dipping structures, interpreted as shear zones, which detach on a major west-dipping structure at depth. The east-dipping structures are interpreted as back-thrusts accommodating bulk shortening and thickening of the turbidite pile. These structures may have been responsible for bringing high-grade migmatised pelites and gneisses from the lower parts of the turbidite pile to the surface in hanging-wall positions. These rocks, which are observed to crop out in some places (Duggan and Scott, 2000) are associated with aureole zones around Silurian granite intrusions, which also appear to be controlled by the shear zones. A whole-of-crust style is also apparent in highly reflective sequences, interpreted to be Junee-Narromine Volcanic Belt (JNVB) volcanic rocks. These are folded into a mid-crustal antiform (Fig. 4 c, d: units 26, 30). Thrusts, constrained by the petrophysical property contrasts across them, are developed at both the structural top and base of inferred Ordovician volcanics (sensu lato, s.l.); at the top of inferred Ordovician Jindalee Group; and above/within the Silurian basin packages. The upper parts of these packages can be modelled with thin slices that have distinct higher frequency 'sawtooth' gravity and magnetic signatures. The Gilmore Fault Zone (GFZ) was previously inferred to be a major terrane boundary (Scheibner, 1985) or major trans-orogenic structure
(Glen, 1992). It is interpreted here to be a relatively minor series of mostly east-dipping Late Silurian-Early Devonian splays off a major west-dipping Late Ordovician or Early Silurian detachment. This geometry is similar in character (although not kinematics) to the situation postulated by Stuart-Smith (1991), which he based on evidence from outcrops south of our study area. The reinterpretation of the GFZ from our study has implications for crustal reconstructions, particularly in Victoria (e.g., VandenBerg et al., 2000) that link the GFZ with the Late Silurian-Early Devonian Indi Fault in Victoria (Morand and Gray, 1991). A component of strike-slip movement on the GFZ also appears to have controlled the opening and subsequent inversion of part of the Jemalong Trough (Lyons, 2000a).

2. Large volumes of Ordovician volcanic rocks are inferred to underlie the constituent Parkes-Narromine and Temora-Lake Cowal Belts, which are structurally linked beneath the Currowong Syncline of the Jemalong Trough (Fig. 4d). The potential field data also confirm interpretation of a thick, dense $\left(2.78-2.82 \times 10^{3} \mathrm{~kg} \mathrm{~m}^{-3}\right)$ packet of Ordovician volcanics (s.1.) underlying the less dense $\left(2.72 \times 10^{3} \mathrm{~kg} \mathrm{~m}^{-3}\right)$ Wagga Group to the west. The thickest part of the arc appears to occur in a domed body of moderate density $\left(2.68 \times 10^{3} \mathrm{~kg} \mathrm{~m}^{-3}\right)$ associated with outcropping Lake Cowal Volcanic Complex (LCVC: Lyons, 2000b). This body, which is not dissected by any of the major reflective shear zones, is also associated with deep-seated circular features in multi-scale edge data sets (Direen et al., 2000). The LCVC, and similar features along strike to the north, probably represent in situ feeder zones in the original Macquarie Arc.

3. All occurrences of Ordovician turbidites are modelled as slices, either detaching on Ordovician volcanic packages (e.g., Wagga Group and Kirribilli Formation: Fig. 4b and Fig. 4d respectively), or on Silurian basin rocks (e.g., Girilambone Group, unit 11 Fig. 4b). The limited thickness of the Girilambone Group example in Fig. 4b is constrained by its strong density contrast $\left(2.65 \times 10^{3} \mathrm{~kg} \mathrm{~m}^{-3}\right)$ with the underlying clastic rocks $\left(2.55 \times 10^{3} \mathrm{~kg} \mathrm{~m}^{-3} \max \right)$; initial estimates from seismic reflection assumed a much greater thickness $(\sim 1 \mathrm{sec}$ TWT or $\sim 3000 \mathrm{~m}$ ) than implied by the gravity anomaly (Fig. 4e). The Silurian-Devonian trough packages are either parts of thick inverted basins or high-level slivers sliced off them. The former is exemplified by the Currowong Syncline (Fig. 4d). This folded basin is distinguished by the inferred presence of dense $\left(2.80 \times 10^{3} \mathrm{~kg} \mathrm{~m}^{-3}\right)$, magnetic $(0.03-0.05 \mathrm{SI})$ volcanics, probably basalts, derived by melting Ordovician source rocks (Raymond et al., 2000c). These act as marker units, producing high frequency magnetic anomalies. A second Silurian-Devonian depocentre of the Jemalong Trough is inferred to have formed along the GFZ (Figs. 4b, 5b). The initial seismic interpretation across the GFZ in line 99AGSL3 did not include this depocentre (Fig. 5c); it was inferred from the strong negative Bouguer anomaly, which precludes dense Ordovician volcanics $\left(2.75 \times 10^{3} \mathrm{~kg} \mathrm{~m}^{-3}\right)$ in this position. Thrusting of thin, shallowly dipping slices over the top of the Jemalong Trough (e.g., Fig. 4b) indicates a minimum Carboniferous age for a significant portion of the crustal fabric.

4. Although not imaged in the seismic reflection data, Silurian granites in the Wagga Group are inferred, from gravity data, to be tabular, with floors at $3 \mathrm{~km}$ to $7 \mathrm{~km}$ (Figs. 5a, c). The model is not sensitive to shape of the granite margins. This contrasts with the Devonian Mortray Hill Granite Complex (Fig. 4d), which appears to be cylindrical to considerable depth. The Barmedman and Thurungly Granites (Fig. 5b) are different again, comprising composite, high-level puck-shaped intrusions floored at about $2-3 \mathrm{~km}$.

5. In all three models, mid- to lower-crustal packages with repeated bands of high reflectivity are modelled with extensive high density $\left(2.85 \times 10^{3} \mathrm{~kg} \mathrm{~m}^{-3}\right)$ bodies that produce the overall 
level of the regional gravity field. Test models (not shown) indicate that the lower crust can be modelled using combinations of Ordovician volcanics $\left(2.75-2.85 \times 10^{3} \mathrm{~kg} \mathrm{~m}^{-3}\right)$, Ordovician metaturbidites $\left(2.72-2.78 \times 10^{3} \mathrm{~kg} \mathrm{~m}^{-3}\right)$, and Jindalee Group MORB metavolcanics $\left(2.80-2.85 \times 10^{3} \mathrm{~kg} \mathrm{~m}^{-3}\right)$. However, given the uncertainties involved in interpretation at these depths, we have chosen to not differentiate these sources. In any case, the attributed densities are consistent with a range of lower crustal rock types, including serpentinites, greenstones, amphibolites, slates, schists, and mafic gneisses (Emerson, 1990). These sources are similar to those associated with the high $\mathrm{P}$-wave velocities in the lower crust (6750 -7000 $\mathrm{ms}^{-1}$, Finlayson et al., 1998), inferred to be dolerite, mafic orthogneisses and amphibolite. These inferred compositions support the hypothesis that basement to the eastern Lachlan Orogen consists of stacked slices of oceanic crust and metaturbidites, possibly of mixed Cambrian and Ordovician age.

\section{Crustal architecture of the Molong Volcanic Belt and flanking} basins

Uninterpreted seismic sections for the three 1997 seismic lines are shown in Figure 6, with the final models of the interpretations also shown. The following conclusions, again, addressing the six questions posed, have been drawn from the models:

1. Mapping of the northern part of the MVB (e.g., Glen, 1998b) has identified a system of north-south trending thrust-faults with both east- and west-vergence. These structures bound imbricate slices of Silurian-Devonian sedimentary rocks and Ordovician volcanics (s.l.) In the seismic reflection data (Figs. 6c, e), both the Molong and Godolphin faults, which form the boundaries to the MVB, are imaged with strong east-dipping reflections. Several other faults are also imaged with east-dipping reflections between these bounding faults; all faults appear to detach onto a sub-horizontal surface at about $5 \mathrm{~s}$ TWT. Modelling of magnetic data support the interpretation of thin, interleaved east-dipping slices of Ordovician volcanics and Silurian-Devonian sedimentary sequences. The contrasting properties of these packages give rise to asymmetric, low amplitude 'saw tooth' anomalies (Figs. 6d, f). Models indicate master thrust horizons inferred from property contrasts above and below the magnetic Ordovician volcanics (s.l.), which are mechanically competent. The Molong Fault (MF, Fig. 6d) appears to be an early thrust reactivated during the Carboniferous. It carries denser $\left(2.63 \times 10^{3} \mathrm{~kg} \mathrm{~m}^{-3}\right)$, magnetic Ordovician volcanics (up to $0.04 \mathrm{SI}$ ), onto the lower density, $\left(2.60 \times 10^{3} \mathrm{~kg} \mathrm{~m}^{-3} \mathrm{max}\right)$, weakly magnetic Silurian-Devonian sedimentary rocks (0.005 SI max) of the Cowra Trough and overlying Late Devonian Catombal Group. The Godolphin Fault, and linked thrusts such as the Wilga Glen Fault (Fig. 6f; Glen, 1998b) in the east of MVB, sole onto magnetic Ordovician volcanics (0.06 SI max), and imbricate the variably magnetic Silurian-Devonian Mumbil Shelf rocks (0.005-0.01 SI). Glen et al. (1998a) inferred both sets of faults to be reactivated Silurian extensional systems. The southern margin of the MVB (Figs. 6a, b) also shows an imbricated character, interpreting the stacked, strongly reflective zones to $5 \mathrm{~s}$ TWT as Ordovician volcanics $(s . l)$ which project to, and are mapped at the surface (e.g., Glen and Wyborn, 1997). The poorly reflective upper parts of the section (to $2 \mathrm{~s}$ TWT) are modelled with dense $\left(2.66-2.74 \times 10^{3} \mathrm{~kg} \mathrm{~m}^{-3}\right)$, magnetic volcanics (up to $0.07 \mathrm{SI}$ max) that have apparent dip to the south beneath the lower density $\left(2.58 \times 10^{3} \mathrm{~kg} \mathrm{~m}^{-3}\right)$ Silurian Wyangala Batholith. The more reflective middle parts have much lower model densities $\left(2.60-2.63 \times 10^{3} \mathrm{~kg} \mathrm{~m}^{-3}\right)$, but are also quite magnetic (up to $0.03 \mathrm{SI}$ ). The lower model densities may imply that parts of this section also contain extensive volumes of granite, or low density metasedimentary slices. The broad change in apparent strike has been interpreted as a response to early NE-SW shortening in the eastern Lachlan Orogen (Glen and Walshe, 1999; Glen and Wyborn, 1997). Alternatively, it may be related to a northeast-trending lateral ramp in the thrust package, which is suggested by inflections in the gravity and magnetic images at this position (Figs. 2a, b).

2. Bodies representing the Ordovician volcanics (s.l.) are mostly interpreted using their high susceptibilities (up to $0.07 \mathrm{SI}$ ), and their association with bands of high reflectivity. The latter property is inferred to be related to interbedding of packages of lavas and volcaniclastic sediments, giving rise to a high acoustic impedance contrast. Where these bodies are interpreted in the MVB, they generally have modelled densities ranging from $2.60 \times 10^{3} \mathrm{~kg} \mathrm{~m}^{-3}$ to $2.74 \times 10^{3} \mathrm{~kg} \mathrm{~m}^{-3}$. These are lower than average values for mafic volcanics $\left(2.75-3.0 \times 10^{3} \mathrm{~kg} \mathrm{~m}^{-3}\right.$; Emerson, 1990), and are also significantly lower than the range inferred for the JNVB $\left(2.62-2.85 \times 10^{3} \mathrm{~kg} \mathrm{~m}^{-3}\right)$. This may indicate more intermediate compositions and/or a greater ratio of volcaniclastic to intrusive facies in the MVB. Both scenarios are consistent with the MVB being the rifted off forearc or volcaniclastic apron of a magmatic arc centred on the JNVB. As in the JNVB, all models are consistent with considerable volumes of denser Ordovician volcanic-intrusive rocks underlying the low density Silurian-Devonian sedimentary packages of the Mumbil Shelf, and the Cowra and Hill End Troughs. However, compared to the JNVB, the smaller overall volume, lack of identifiable deep-seated magmatic complexes, and imbricated structural style, support the hypothesis that the MVB is an allochthonous fragment rifted from the main part of Macquarie Arc during the Early Silurian (Glen et al., 1998b), rather than a separate arc (Fergusson and Coney, 1992).

3. The relationships between the Ordovician Adaminaby Group turbidites and the Ordovician volcanogenic rocks of the MVB are unclear in the seismic reflection data. At the southern end of the belt, an asymmetric magnetic anomaly is modelled by a thin, north-dipping package of weakly magnetic Adaminaby Group (0.002 SI), possibly caught up along a back-thrust (Fig. 6b). However, due to the intrusion of the Wyangala Batholith in this position, and the possibility that the section crosses a lateral thrust ramp as outlined above, no general conclusions can be drawn from this relationship.

4. As in the JNVB, Silurian-Devonian sedimentary packages occur as either in situ basins, or structural slivers. In situ low density, weakly magnetic basins (Cowra and Hill End Troughs) are developed over denser, magnetic Ordovician arc volcanics (s.l.). These basins have been modified by Middle Devonian (Glen and Watkins, 1999) and Carboniferous upper crustal deformation, along with the underlying volcanic substrate. Thin slices derived from these basins occur both on and adjacent to the MVB.

5. Silurian (Wyangala Batholith, Fig. 6a), Devonian (Gumble Granite, Fig. 6d), and Carboniferous (Bathurst Batholith, Fig. 6f) granites are interpreted in the models, despite having no internal seismic reflectivity patterns or distinct seismic 'edges'. The Silurian example is a magnetically complex, composite intrusion with varying magnetic susceptibility. It is floored by an inferred thrust at about $5 \mathrm{~km}$, in agreement with gravity filtering and modelling of Lennox and Trzebski (2001). The low density $\left(2.57 \times 10^{3} \mathrm{~kg} \mathrm{~m}^{-3}\right)$, magnetically bland $(\sim 0 \mathrm{SI})$ Devonian example is puck-shaped, with a floor at approximately $3 \mathrm{~km}$. Although not initially interpreted in the seismic data, the Carboniferous Bathurst Batholith is inferred from multi-scale edge data sets as shelving beneath the western edge of the Hill End Trough (Archibald et al., 2001b), and is modelled as a thick, uniform wedge between $4 \mathrm{~km}$ and $12 \mathrm{~km}$ depth.

6. As in the JNVB, mid- to lower-crustal packages with repeated bands of high reflectivity are modelled with extensive high density $\left(2.85 \times 10^{3} \mathrm{~kg} \mathrm{~m}^{-3}\right)$ bodies that produce the overall level 
of the regional gravity field. A range of possible sources are consistent with this interpretation, and with the hypothesis that basement to the MVB consists of stacked slices of oceanic crust and metaturbidites, possibly of mixed Cambrian and Ordovician age.

\section{SYNTHESIS}

Integrated analysis of geophysical and geological data sets supports an overall Palaeozoic history of the eastern Lachlan Orogen with the following sequence of events:

1. Formation of an extensive package of Ordovician intrusive, volcanic and volcaniclastic rocks, thickest where the Northparkes Volcanic Group crops out. We interpret this succession to be the Macquarie Arc of Glen et al. (1998b), which was built on a relatively dense, reflective basement, probably modified ocean crust volcanics, and metaturbidites, similar to the greenstone basement in the western Lachlan Orogen (Crawford and Keays, 1978). This accords with the interpretation of P- wave velocities for the lower crust recorded in Finlayson et al. (1998).

2. Late Ordovician to Early Silurian east-directed overthrusting placed Ordovician turbidite packages west of the JNVB, and floored by volcanics, over the arc. This event produced substantial stacking and repetition (100-200\%) of the underlying basement sequences. It may represent collapse of the backarc basin over the arc, possibly similar to the modern-day Wetar thrust belt in Indonesia (Breen et al., 1989). The deep crustal thrusts formed in this event bound the original arc (?LCVC), its probable back-arc basin (Wagga Group), and a probable intra-arc rift (Jindalee Group: Lyons, 2000b).

3. Generation of Silurian granites, possibly by melting of the turbidites at significant depths under the thrust stack, although the specific origin of the heat source is unknown. These granites may have then intruded the deforming turbidite pile by exploiting shear zones that were accommodating the structural thickening.

4. Early Silurian to Middle Devonian rifting, forming sedimentary packages with interbedded rift volcanics. This event resulted in the dismemberment of the deformed arc, to form the apparently deep-rooted $(15 \mathrm{~km}+)$ Junee-Narromine Volcanic Belt, and the thinner, probably allochthonous Molong (and by inference, Rockley-Gulgong) Volcanic Belt. These arc slivers were separated by marine basins (Jemalong, Cowra, and Hill End Troughs), some containing volcanics derived from melting of the underlying Ordovician 'floor' (Raymond et al., 2000c).

5. Deformation of these basins during the Early-Middle Devonian, accompanied by some plug-like granite magmatism.

6. Late Devonian terrestrial sedimentation (Catombal, Lambie, and Hervey Groups).

7. Carboniferous upper crustal folding and thrust stacking involving both east- and west-directed transport. This event reworked the upper structural level of earlier antiformal stacks, and top-planed basins and granite roof zones alike. Late Devonian successor basins were inverted in footwall syncline positions.

8. Carboniferous granite magmatism, forming composite batholiths such as the Bathurst Batholith.

\section{ACKNOWLEDGEMENTS}

AGSO-AGCRC authors publish with the permission of the CEO, AGSO. RAG publishes with the permission of the Director General, New South Wales Department of Mineral Resources. Geophysical data are published with the permission of AGSO and the New South Wales Department of Mineral Resources. Leonie Jones and David Johnstone are thanked for their leading role in processing the seismic data; Malcolm Nicoll undertook gravity acquisition and tedious digitising of interpreted sections. Tim Mackey and Mario Bacchin are thanked for merging and processing magnetic data sets for this study. Ollie Raymond, George Gibson, Sydney Hall, Leonie Jones, Bruce Goleby, Bruce Simons, Peter Wellman and Phil Schmidt are all thanked for helpful reviews that improved the quality of the manuscript.

\section{REFERENCES}

Archibald, N. J., Hill, E. J., Direen, N. G., Lyons, P., Raymond, O. L., Holden, D., Mason, R., and Korsch, R. J., 2001a, AGCRC-Fractal Graphics northeastern Lachlan Orogen Project. In: R. J. Korsch and P. Lyons (Editors), 2001a, AGSO Record 2001/09, 59

Archibald, N. J., Hill, E. J., Direen, N. G., Lyons, P., Raymond, O. L., Holden, D., Mason, R., and Korsch, R. J., 2001b, Wavelet-based edge detection processing (worming) and interpretation of magnetic and gravity data sets, northeastern Lachlan Orogen Project. In: R. J. Korsch and P. Lyons (Editors), 2001, AGSO Record 2001/09, 60-65.

Bacchin, M., Duggan, M., Glen, R., Gunn, P., Lawrie, K., Lyons, P., Mackey, T., Raphael, N., Raymond, O., Robson, D., and Sherwin, L., 1999, Cootamundra, Interpreted geology based on geophysics and previous geological mapping, (1:250 000 scale map). Australian Geological Survey Organisation, Canberra and Geological Survey of New South Wales, Department of Mineral Resources.

Breen, N. A., Silver, E. A., and Roof, S., 1989, The Wetar back arc thrust belt, eastern Indonesia: the effect of accretion against an irregularly shaped arc: Tectonics, $\mathbf{8}$, 85-98.

Collins, W. J., 1998, Evaluation of petrogenetic models for Lachlan Fold Belt granitoids: implications for crustal architecture and tectonic models: Australian Journal of Earth Sciences, 45, 483-500.

Crawford, A. J., and Keays, R. R., 1978, Cambrian greenstone belts in Victoria: marginal sea-crust slices in the Lachlan Fold Belt of southeastern Australia: Earth and Planetary Science Letters, 41, 197-208.

Direen, N. G., Archibald N. J., Hill, E. J., Mackey, T. E., Raymond, O. L., Lyons, P., Korsch, R. J., and Holden, D. J. 2000. "Annelidical geometry": a 3-D geological and geophysical appraisal of major structures in the eastern Lachlan Orogen using multi-scale edge analysis. In: C. G Skilbeck and T. C. T. Hubble (Editors), 2000, Geological Society of Australia Abstracts 59, 132.

Duggan., M. B., and Scott, M. M., 2000, Wagga Group. In: P. Lyons, O. L. Raymond and M. B. Duggan, (Editors), Forbes 1:250 000 Geological Sheet SI55-7, second edition, Explanatory Notes: AGSO Record, 2000/20, 9-13.

Emerson, D. W., 1990, Notes on mass properties of rocks -density, porosity, permeability: Exploration Geophysics, 21, 209-216.

Evans, D. J., Rowley, W. J., Chadwick, R. A., Kimbell, G. S., and Millward, D., 1994 Seismic reflection data and the internal structure of the Lake District batholith, Cumbria, northern England: Proceedings of the Yorkshire Geological Society, 50, $11-24$

Fergusson, C. L., and Coney, P. J., 1992, Implications of a Bengal-Fan-type deposit in the Palaeozoic Lachlan fold belt of southeastern Australia: Geology, 44, 831-852.

Finlayson, D. M., Leven, J. H., Owen, A., Barton, T., and Johnstone, D. W., 1998, Wideangle seismic profiling and crustal architecture along the Molong-Wyangala structural zone, eastern Lachlan Orogen -preliminary interpretation. In: D. M. Finlayson and L. E. A. Jones, (Editors), 1998, AGSO Record, 1998/2, 69-73.

Gibson, D. L., and Chan, R. A., 1999, Forbes regolith-landforms, 1:250 000 sheet. Cooperative Research Centre for Landscape Evolution and Mineral Exploration, Canberra.

Glen, R. A., 1992, Thrust extensional and strike-slip tectonics in an evolving Palaeozoic orogen - a structural synthesis of the Lachlan Orogen of southeastern Australia: Tectonophysics 214, 341-380.

Glen, R. A., 1995, Thrusts and thrust-associated mineralisation in the Lachlan Orogen: Economic Geology, 90, 1402-1429.

Glen, R. A., 1998a, The Eastern Belt of the Lachlan Orogen. In: D. M. Finlayson and L. E. A. Jones, (Editors), 1998, AGSO Record, 1998/2, 80-82.

Glen, R. A., 1998b, Structural geology. In: D. J. Pogson and J. J. Watkins (Editors), 1998, Bathurst 1:250 000 Geological Sheet SI55-8, Explanatory Notes. Geological Survey of New South Wales, Sydney. Pp.287-310.

Glen, R. A., and Walshe, J. L., 1999, Cross-structures in the Lachlan orogen: the Lachlan Transverse Zone example: Australian Journal of Earth Sciences, 46, 641658 .

Glen, R. A., and Watkins, J. J., 1999, Implications of Middle Devonian deformation west of the Hill End Trough, Lachlan Orogen, New South Wales: Australian Journal of Earth Sciences, 26, 35-52. 
Glen, R. A., and Wyborn D., 1997, Inferred thrust imbrication, deformation gradients and the Lachlan Transverse Zone in the Eastern Belt of the Lachlan Orogen, New South Wales: Australian Journal of Earth Sciences, 44, 49-68.

Glen, R. A., Korsch, R. J., Jones, L. E. A., Direen, N. G., Johnstone, D. W., Lawrie, K. C., Finlayson, D. M., and Shaw, R. D., in press, Crustal structure of the Ordovician Macquarie Arc, eastern Lachlan Orogen, based on seismic reflection profiling: responses to contractional and extensional deformation. Australian Journal of Earth Sciences.

Glen, R. A., Korsch, R. J., Jones, L. E. A., Lawrie, K. C., Shaw, R. D., and Johnstone, D. W., 2001, Crustal architecture of the Ordovician Macquarie Arc, eastern Lachlan Orogen, NSW, based on deep seismic reflection data. In: R. J. Korsch and P. Lyons (Editors), 2001, AGSO Record 2001/09, 45-48.

Glen, R. A., Korsch, R. J., Jones, L. E. A., and Johnstone, D. W., 2000, Seismic evidence for a major arc-back arc collision in the Lachlan Orogen. In: C. G Skilbeck and T. C. T. Hubble (Editors), 2000, Geological Society of Australia Abstracts 59, 177.

Glen, R. A., Korsch, R. J., and Johnstone D. W., 1998a. Crustal structure of eastern Lachlan Orogen based on preliminary interpretation of $4 \mathrm{sec}$ TWT seismic reflection data. In: D. M. Finlayson and L. E. A. Jones, (Editors), 1998, AGSO Record, 1998/2, 83-84.

Glen, R. A., Walshe, J. L., Barron, L. M., and Watkins, J. J., 1998b, Ordovician convergent margin volcanism and tectonism in the Lachlan sector of east Gondwana: Geology, 26, 751-754.

Jones, L. E. A., and Johnstone, D. W., 2001, Acquisition and processing of the 1997 Eastern Lachlan (L146) and 1999 Lachlan (L151) seismic reflection surveys. In: R. J. Korsch and P. Lyons (Editors), 2001, AGSO Record 2001/09, 26-35.

Leaman, D. E., 1994, Criteria for evaluation of potential field interpretations: First Break, 12, 181-191.

Lennox, P. G., and Trzebski, R., 2001, Gravity signature of some plutons of the eastern Lachlan Orogen. In: R. J. Korsch and P. Lyons (Editors), 2001, AGSO Record 2001/09, 49-53.

Lyons, P., 2000a, 2. Geological History. In: P. Lyons, O. L. Raymond and M. B. Duggan, (Editors), Forbes 1:250 000 Geological Sheet SI55-7, second edition, Explanatory Notes: AGSO Record, 2000/20, 3-6.

Lyons, P., 2000b, Lake Cowal Volcanic Complex. In: P. Lyons, O. L. Raymond and M. B. Duggan, (Editors), Forbes 1:250 000 Geological Sheet SI55-7, second edition, Explanatory Notes: AGSO Record, 2000/20, 17-19.

Lyons, P., Raymond, O. L., and Duggan, M. B., 2000a, (Editors), Forbes 1:250 000 Geological Sheet SI55-7, second edition, Explanatory Notes: AGSO Record, 2000/20.
Lyons, P., Duggan, M. B., and Wallace, D. W., 2000b, Jindalee Group. In: P. Lyons, O. L. Raymond and M. B. Duggan, (Editors), Forbes 1:250 000 Geological Sheet SI55-7, second edition, Explanatory Notes: AGSO Record, 2000/20, 7-9.

MacCorquodale, F., 1996, EL3620 -Barmedman East Annual Exploration Progress Report 31 July 1995 to 31 July 1996 Volume 1, Unpublished New South Wales Department of Mineral Resources Report 1996/080.

Morand V. J. and Gray D. R., 1991, Major fault zones related to the Omeo metamorphic Complex, northeastern Victoria: Australian Journal of Earth Sciences, 38, 203-222.

Murray, A. S., 2000, Australian National Gravity Database, 2000 release. Australian Geological Survey Organisation, Canberra.

Pogson, D. J., and Watkins, J. J., 1998. Bathurst 1:250 000 Geological Sheet SI55-8, Explanatory Notes. Geological Survey of New South Wales, Sydney 430 pp.

Raymond, O., Mackey, T., and Lyons, P., 2000a, North-eastern Lachlan Fold Belt (1:500 000 scale solid geology map). Australian Geodynamics Co-operative Research Centre, Australian Geological Survey Organisation, Canberra.

Raymond, O., Gibson, D. L., and Chan, R.A., 2000b, Forbes (SI55-7) Depth to weathered bedrock, 1:250 000 scale map (First edition). Australian Geological Survey Organisation, Canberra.

Raymond, O., Sherwin L., Lyons P., and Scott M., 2000c, The Jemalong Trough: an extension of Siluro-Devonian rifting in the eastern Lachlan Fold Belt. In: C. G Skilbeck and T. C. T. Hubble (Editors), 2000, Geological Society of Australia Abstracts 59, 409.

Richardson, L. M., 2000, Index of airborne geophysical surveys. AGSO Record, 2000/07.

Scheibner E., 1985, Suspect terranes in the Tasman Fold Belt System, eastern Australia. In: D. G. Howell (Editor), 1985, Tectonostratigraphic terranes of the Circum-Pacific Region. Circum-Pacific Council for Energy and Mineral Resources, Earth Science Series 1, 493-514.

Stuart-Smith P. G., 1991, The Gilmore Fault Zone - the deformational history of a possible terrane boundary within the Lachlan Fold Belt, New South Wales. BMR Journal of Australian Geology and Geophysics 12, 35-50.

VandenBerg A. H. M, Willman C. E., Maher S., Simons B. A., Cayley R. A., Taylor D. H., Morand V. J., Moore D. H., and Radojkovic A., 2000, The Tasman Fold Belt System in Victoria. Geological Survey of Victoria Special Publication, Melbourne, Australia. 462 pp.

Vigneresse, J. L., 1990, Use and misuse of geophysical data to determine the shape at depth of granitic intrusions, Geological Journal, 25, 249-260.

Warren, A. Y. E., Gilligan, L. B., and Raphael, N. M., 1996, Cootamundra 1:250 000 Geological Sheet SI55-11, Explanatory Notes. Geological Survey of New South Wales, Sydney 160 pp. 